\title{
PERSEPSI NASABAH TERHADAP PROGRAM TABUNGAN RENCANA BERHADIAH PADA BANK MUAMALAT KCP ABEPURA
}

\author{
Abd. Karman \\ IAIN Fattahul Muluk Papua \\ abdul.karman@iainfmpapua.com \\ Nur Afifah \\ IAIN Fattahul Muluk Papua \\ nurafifahramadani@gmail.com
}

\begin{abstract}
As the first Islamic commercial bank in Indonesia, since 1992, Muamalat Bank has always won the trust of the public as a bank that provides programs. It also services based on Islamic principles. one of its program is BPS TRB program (Bank that Receives Savings on Savings for Savings Plan for Rewards) which was developed in 2017 with a number of customers overall since 2017-2020. There are 306 customers of the program. The research problems in this thesis are how is the mechanism of prize-savings plan program at Abepura Branch Office of Bank Muamalat and how is the customer's perception of the prize-savings plan program at Abepura Branch Office of Bank Muamalat. This thesis aims to analyze the mechanism of the prize plan savings and analyze customer perceptions of prize-savings plan program at Abepura Branch Office of Bank Muamalat.

In this research, the writer uses descriptive qualitative research. The data obtained will be represented and analyzed to produce a conclusion. Data obtained from primary data and secondary data. The methods of observation, interviews and documentation are also conducted to obtain complete data.

The results of this study indicate that the mechanism of saving prize-savings plan program is carried out according to the terms and conditions that have been applied.It is easily understood by the customer. The contract used in accordance with Islamic law is mudharabah agreement (profit sharing) where the customer will get a $7.5 \%$ ratio every month. Customer's perception of prize-savings plan program is considered to be very good and profitable because the program can help the customer to arrange financial plans in the future with a view to the child's future.
\end{abstract}

Keywords : Mechanism, Perceptions

\begin{abstract}
ABSTRAK
Sebagai bank umum syariah pertama di Indonesia, sejak tahun 1992 Bank Muamalat selalu mendapat kepercayaan dari masyarakat sebagai bank yang menyediakan program dan layanan yang berdasarkan prinsip syariah salah satunya program BPS TRB (Bank Penerima Setoran Tabungan Rencana Berhadiah) yang dikembangkan pada tahun 2017 dengan jumlah nasabah secara keseluruhan sejak tahun 2017-2020 adalah 306 nasabah. Rumusan masalah dalam skripsi ini adalah Bagaimana mekanisme program tabungan rencana berhadiah pada Bank Muamalat KCP Abepura dan Bagaimana persepsi nasabah terhadap program tabungan rencana berhadiah pada Bank Muamalat KCP Abepura. Skripsi ini bertujuan untuk menganalisis mekanisme tabungan rencana berhadiah dan menganalisis persepsi nasabah terhadap program tabungan rencana berhadiah pada Bank Muamalat KCP Abepura.
\end{abstract}


Dalam penelitian ini, penulis menggunakan jenis penelitian kualitatif deskriptif. Data yang didapatkan akan diintrepresentasikan dan dianalisis sehingga menghasilkan sebuah kesimpulan. Data yang diperoleh berasal dari data primer dan data sekunder.Metode observasi, wawancara dan dokumentasi juga dilakukan untuk memperoleh data yang lengkap.

Hasil penelitian ini menunjukkan bahwa mekanisme tabungan rencana berhadiah dilakukan sesuai syarat dan ketentuan yang telah diterapkan, mudah dimengerti oleh nasabah dan akad yang digunakan sesuai syariat Islam yaitu akad mudharabah (bagi hasil) dimana nasabah akan memperoleh nisbah 7,5\% setiap bulannya. Persepsi nasabah terhadap program tabungan rencana berhadiah dianggap sangat baik dan menguntungkan, karena program tersebut dapat membantu nasabah untuk mengatur rencana keuangan dikemudian hari dengan tujuan untuk masa depan anak.

Kata Kunci : Mekanisme, Persepsi

\section{PENDAHULUAN}

Hampir semua sektor yang berhubungan dengan berbagai keuangan selalu membutuhkan jasa bank. Oleh karena itu, saat ini dan disaat yang akan datang tidak akan lepas dari dunia perbankan. Begitu pentingnya dunia perbankan sehingga ada anggapan bahwa bank merupakan "nyawa" untuk menggerakkan roda perekonomian suatu negara. Perkembangan zaman yang semakin melaju pesat, saat ini muncul lembaga keuangan syariah yang menjadi kompetitor dari lembaga keuangan konvensional. Salah satu bukti dari perkembangan Bank Syariah di Indonesia adalah hadirnya Bank Muamalat Indonesia, yang merupakan salah satu bentuk dari eksistensi perkembangan Lembaga Keuangan Syariah.

Respon masyarakat yang besar atas kehadiran Bank Muamalat Indonesia dalam melaksanakan fungsinya sebagai lembaga keuangan yang menganut prinsip syariah. Dengan kehadiran Bank Muamalat Indonesia yang menawarkan program Tabungan Rencana Berhadiah diatas bagi nasabah yang ingin berinvestasi. Hal ini dapat memberikan keuntungan yang memuaskan kepada nasabah.

Sebagai bank umum syariah pertama di Indonesia, sejak tahun 1992 Bank Muamalat selalu mendapat kepercayaan dari masyarakat sebagai bank yang menyediakan program dan layanan yang berdasarkan prinsip syariah salah satunya program BPS TRB (Bank Penerima Setoran Tabungan Rencana Berhadiah) yang dikembangkan pada awal 2017 dengan jumlah nasabah secara kesulurahan sejak awal tahun 2017-2020 adalah 306 nasabah (Mokan \& Rosikun, 2020).

Tujuan penelitian untuk mengetahui bagaimana mekanisme program Tabungan Rencana Berhadiah (TRB) di Bank Muamalat KCP Abepura dan untuk mengetahui bagaimana persepsi nasabah terhadap program Tabungan Rencana Berhadiah (TRB) di Bank Mumalat KCP Abepura.

Manfaat penelitian Bagi Khazanah Ilmu Pengetahuan, penelitian ini dapat berguna untuk memberikan penjelasan dan pemahaman mengenai persepsi nasabah terhadap program tabungan rencana berhadiah di Bank Muamalat KCP Abepura. Selain itu, penulisan penelitian ini juga diharapkan dapat menjadi sumber bacaan yang dapat menambah wawasan bagi mahasiswa khususnya program studi Perbankan Syariah. Bagi masyarakat, hasil dari penelitian ini diharapkan mampu memberikan informasi kepada masyarakat luas sehingga dapat menjadi sebuah referansi baru untuk menarik minat masyarakat untuk bergabung atau menjadi nasabah di Bank Muamalat KCP Abepura. Bagi Instansi Tempat Penelitian, 
kegunaan penelitian ini untuk instansi yang bersangkutan yaitu agar dapat menjadi bahan pertimbangan dan evaluasi serta memberikan masukan-masukan yang bermanfaat untuk instansi tersebut dalam meningkatkan jumlah nasabah pada tabungan rencana berhadiah (TRB).

\section{KAJIAN LITERATUR}

1. Mekanisme

Mekanisme berasal dari bahasa Yunani "Mechane" yang berarti instrument pengangkat beban, perangkat, peralatan, untuk membuat sesuatu; dan dari kata "Mechos" yang berarti sarana dan cara menjalankan sesuatu. Kata mekanisme berasal dari kata mekanik yang artinya cara kerja yang digunakan untuk pengoperasian dalam menjalankan sesuatu yang diperlukan agar lancar dalam pengambilan manfaatnya (pusat bahasa.diknas.go.id, 2020). Dengan demikian, mekanisme adalah sebuah proses pelaksanaan suatu kegiatan yang dilaksanakan oleh seseorang atau beberapa orang dengan menggunakan tatanan aturan serta adanya alur komunikasi dan pembagian tugas sesuai dengan profesionalitas.

2. Program Tabungan Rencana Berhadiah

a. Pengertian Program Tabungan Rencana Berhadiah

Program tabungan rencana berhadiah merupakan program tabungan yang akan membantu nasabah untuk mengatur rencana keunagan dikemudian hari dimana Tabungan Rencana Berhadiah ini menggunakan akad mudharabah (bagi hasil) yang terbebas dari biaya administrasi bulanan. Program Tabungan rencana berhadiah merupakan tabungan yang bertujuan untuk mewujudkan keinginan nasabah untuk mendapatkan hadiah yang diinginkan tanpa melalui proses pengundian. Pada program TRB ini nasabah berhak mendapatkan kembali dana setoran awal, setoran setiap bulan dan bagi hasil tabungan serta hadiah yang telah menjadi milik nasabah. Setoran awal yang dimaksud disini adalah sebagai jaminan untuk mendapatkan hadiah dan akan di blokir oleh pihak bank sesuai kesepakatan diawal dan akan diambil sesuai jangka waktu menabung. TRB dapat difungsikan sesuai kebutuhan dan profil nasabah (Iswanti, 2020).

b. Fatwa DSN No. 86/DSN-MUI/XII/2012 tentang Hadiah Dalam Penghimpunan Dana Lembaga Keuangan Syariah.

Dewan Syariah Nasional - Majelis Ulama Indonesia setelah menimbang :

1. Bahwa Lembaga Keuangan Syariah (LKS) melakukan penghimpunan dana berupa tabungan, deposito, dan giro dengan akad yang sesuai syariah, yaitu wadi'ah (titipan) dan mudharabah (bagi hasil).

2. Bahwa dalam rangka minat menarik masyarakat terhadap produk penghimpunan dana, LKS memberikan hadiah kepada nasabah penyimpan, baik berupa hadiah promosi maupun hadiah bagi dana simpanan nasabah.

3. Bahwa industri keuangan syariah dan masyarakat memerlukan kejelasan hukum syariah sebagai landasan operasional pemberian hadiah dalam penghimpunan dana LKS. 
4. Bahwa berdasarkan pertimbangan huruf a, b, dan c, Dewan Syariah Nasional Majelis Ulama Indonesia, memandang perlu untuk menetapkan fatwa tentang hadiah dalam penghimpunan dana LKS untuk dijadikan pedoman.

Mengingat :

Firman Allah SWT dalam Q.S Al-Maidah [5] ayat 1 (Al-Qur'an, 2012, hlm 106). Q.S Al-Isra [17] ayat 34 (Al-Qur'an, 2012, hlm 285). Q.S Al-Baqarah [2] ayat 275 (Al-Qur'an, 2012, hlm 47). dan Q.S An-Nisa [4] ayat 58 (Al-Qur'an, 2012, hlm 87).

3. Persepsi

a. Pengertian Persepsi

Persepsi adalah proses dimana stimuli-stimuli diseleksi, diorganisasikan, dan diinterpretasikan (Kotler, 2008, hlm 179). Persepsi tidak hanya bergantung pada hal fisik, tetapi juga berhubungan dengan lingkungan sekitar dan keadaan individu tersebut. Sedangkan dalam proses memperoleh atau menerima informasi tersebut juga berasal dari objek lingkungan. Persepsi merupakan proses psikologis yang sangat kompleks yang melibatkan aspek fisikologis manusia. Dalam prosesnya, psikologis memiliki peranan yang sangat penting dimulai dari adanya aktivitas memilih, mengorganisasi dan menginterpretasikan sehingga individu dapat memberikan makna atas suatu objek.

b. Proses Terbentuknya Persepsi

Proses stimulus mengenai alat indera merupakan proses kealaman atau proses fisik. Stimulus yang diterima oleh alat indera diteruskan oleh syaraf sensoris ke otak. Proses ini yang disebut sebagai proses fisiologi. Kemudian terjadilah proses di otak sebagai pusat kesadaran sehingga individu menyadari apa yang dilihat, atau apa yang didengar, atau apa yang diraba. Proses yang terjadi dalam otak atau dalam pusat kesadaran inilah yang disebut sebagai proses psikologis.

Dalam proses persepsi perlu adanya perhatian sebagai langkah persiapan dalam persepsi itu. Namun demikian tidak semua stimulus mendapatkan respon individu untuk dipersepsi. Stimulus mana yang akan dipersepsi atau mendapatkan respon individu tergantung pada perhatian individu yang bersangkutan (Walgito, 2003, hlm 87).

Proses persepsi akan dipengaruhi oleh stimulus (faktor luar), faktor internal (faktor dalam, termasuk perhatian), dana struktur pribadi individu. Tetapi tidak semua stimulus akan diperhatikan atau diberikan respon ataupun jawaban terhadap apa yang telah diketahui oleh individu (Walgito, 2003, hlm 90).

c. Faktor Yang Mempengaruhi Persepsi

Faktor-faktor yang mempengaruhi persepsi pada dasarnya dibagi menjadi 2 yaitu Faktor Internal dan faktor Eksternal (Khairani, 2016, hlm 63-65).

a. Faktor Internal yang mempengaruhi persepsi, yaitu faktor-faktor yang terdapat dalam diri individu, yang mencakup beberapa hal antara lain:

1. Fisiologi

Informasi masuk melalui alat inder, selanjutnya informasi yang diperoleh ini akan mempengaruhi dan melengkapi usaha untuk memberikan arti terhadap lingkungan sekitarnya. 
2. Perhatian

Individu memerlukan sejumlah energi yang dikeluarkan untuk memperhatikan atau memfokuskan pada bentukfisik dan fasilitas mental yang ada pada suatu obyek.

3. Minat

Persepsi terhadap suatu obyek bervariasi tergantung pada seberapa banyak energi atau perceptual vigilance merupakan kecenderungan seseorang untuk memperhatikan tipe tertentu dari stimulus atau dikatakan sebagai minat.

4. Kebutuhan

Faktor ini dapat dari bagaimana kuatnya seorang individu mencari obyekobyek atau pesan yang dapat memberikan jawaban sesuai dengan dirinya.

5. Pengalaman

Pengalaman dapat dikatakan tergantung pada ingatan dalam arti sejauh mana seseorang dapat mengingat kejadian-kejadian lampau untuk mengetahui suatu rangsang dalam arti luas.

6. Suasana hati

Keadaan emosi mempengaruhi perilaku seseorang, mood ini menunjukan bagaimana perasaan seseorang pada waktu yang dapat mempengaruhi bagaimana seseorang dalam menerima, bereaksi dan mengingat.

b. Faktor Eksternal yang mempengaruhi persepsi adalah:

1. Ukuran dan penempatan dari obyek atau stimulus

Faktor ini menyatakan bahwa semakin besarnya hubungan suatu obyek, maka semakin mudah untuk dipahami.

2. Warna dari obyek-obyek

Obyek-obyek yang mempunyai cahaya lebih banyak, lebih banyak diminatidari pada yang warnanya lebih sedikit.

3. Keunikan dan kekontrasan stimulus

Stimulus luar yang penampilannya dengan latar belakang dan sekelilingnya yang sama sekali diluar sangka individu lain akan banyak menarik perhatian.

4. Intensitas dan kekuatan dari stimulus

Stimulus dari luar akan memberi makna lebih bila lebih sering diperhatikan dibandingkan dengan yang hanya sekali dilihat.

5. Motion atau gerakan

Individu akan banyak memberikan perhatian terhadap obyek yang memberikan gerakan dalam jangkauan pandang dibandingkan obyek yang diam.

d. Persepsi nasabah

Menurut Saleh dan Wahab istilah persepsi digunakan untuk mengungkapkan tentang pengalaman terhadap suatu benda ataupun sesuatu kejadian yang dialami dimasa lampau (lalu). Menurut Ma'rat menyatakan bahwa persepsi merupakan proses pengamatan seseorang yang berasal dari komponen koqnisi. Persepsi dipengaruhi oleh faktor-faktor pengalaman, proses belajar, cakrawala, dan pengetahuan. Manusia mengetahui suatu objek spikologik ini dapat berupa kejadian, ide, atau situasi tertentu. Pengetahuannya dan cakrawalanya menberikan arti terhadap objek spikologik tersebut (Mar'at, 1986, hlm 22). Melalui persepsi, manusia terus-menerus mengadakan 
hubungan dengan lingkungannya. Hubungan ini dilakukan dengan inderanya, yaitu indera melihat, pendengaran, peraba, perasa dan penciuman (Slameto, 2010, hlm 16). Menurut Suharini persepsi dapat diartikan sebagai proses yang timbul akibat adanya sensasi, yaitu aktivitas merasakan atau penyebab dari keadaan emosi yang menggembirakan. Setiap manusia mempunyai perbedaan persepsi, kepribadian, dan pengalaman hidupnya, sehingga pola berpikir mereka juga akan berbeda-beda. Menurut Firsan secara sederhana mengatakan bahwa persepsi adalah pandangan seseorang dalam menafsirkan suatu peristiwa berdasarkan informasi yang diterimanya. Dari beberapa pendapat diatas, dapat disimpulkan bahwa persepsi nasabah adalah proses dimana nasabah dalam memilih, mengelola, dan menginterprestasikan informasi yang diperoleh dan selanjutnya akan memberikan respon terhadap informasi yang diperoleh tersebut.

\section{METODE PENELITIAN}

1. Metode penelitian

Metode penelitian adalah metode yang digunakan untuk pengumpulan data dalam penelitian jenis metode penelitian meliputi survei, wawancara, observasi, eksperimen, dan lain-lain. Dapat dikatakan bahwa metode penelitian digunakan untuk mengumpulkan informasi, sehingga peneliti dapat menemukan jawaban atas permasalahan penelitiannya. Berdasarkan pada perumusan masalah yang akan diteliti, maka jenis penelitian yang digunakan oleh peneliti dalam penelitian ini adalah penelitian kualitatif (Aminah \& Roikan, 2019, hlm 65). Jenis penelitian ini merupakan penelitian kualitatif yang bersifat deskriptif. Penelitian kualitatif adalah penelitian yang dapat menjelaskan dan menganalisis fenomena, peristiwa, aktivitas sosial, sikap kepercayaan, persepsi seseorang atau kelompok terhadap sesuatu (Hamdi, 2014, hlm 9). Pada penelitian kualitatif deskriptif, data yang dikumpulkan pada umumnya berbentuk kata-kata, gambar, dan kebanyakan bukan bentuk angka. Data yang dimaksud meliputi transkip wawancara, catatan dilapangan, foto-foto, dan dokumen pribadi.

2. Lokasi dan waktu penelitian

Lokasi penelitian yang dilakukan adalah di PT Bank Muamalat Indonesia KCP Abepura Jayapura J1. Raya No. 78, VIM Distrik Abepura Kota Jayapura, Papua-99616. Waktu penelitian yang dilakukan peneliti dalam penelitian ini yaitu salama 83 hari mulai dari tanggal 31 Desember 2019 sampai 23 Maret 2020.

3. Subjek dan objek penelitian

Subjek dalam penelitian ini adalah Nasabah Tabungan Rencana Berhadiah Bank Muamalat KCP Abepura dan Karyawan Bank Muamalat KCP Abepura dan Objek dalam penelitian ini adalah Persepsi.

4. Jenis data dan teknik pengumpulan data

a. Jenis Data

Dalam penelitian ini, peneliti menggunakan dua jenis data, yaitu :

1. Jenis data primer adalah sumber data yang diperoleh secara langsung dari sumbernya, melalui hasil wawancara antara peneliti dengan subjek penelitian. Dalam hal ini melalui informanutamanya yaitu nasabah Tabungan Rencana Berhadiah dan Karyawan PT. Bank Mumalat KCP Abepura. 
2. Jenis data sekunder adalah sumber data yang diperoleh secara tidak langsung dari sumbernya, seperti mengutip dari buku-buku, jurnal, penelitian terdahulu, dan literatur lainnya yang mempunyai relevansi dengan penelitian ini.

b. Teknik Pengumpulan Data

Dalam penelitian ini metode pengumpulan data yang digunakan yaitu :

1. Observasi (Observation)

Metode observasi adalah teknik menghimpun bahan-bahan keterangan yang dilakukan dengan mengadakan pengamatan dan pencatatan secara sistematis terhadap fenomena-fenomena yang dijadikan objek pengamatan (Rangkuti, 2002, hlm 76).

2. Wawancara (interview)

Wawancara yaitu pengumpulan data dengan jalan mengadakan tanya jawab langsung dengan informanyang dianggap mengetahui masalah yang akan dibahas, yakni dalam hal ini nasabah Program Tabungan Rencana Berhadiah dan karyawan PT. Bank Mumalat KCP Abepura.

3. Dokumentasi

Dokumentasi merupakan cara pengambilan data yang diperoleh melalui dokumendokumen. Untuk penelitian ini, dilakukan dengan cara mengkaji dokumendokumen yang terkait dengan penelitian ini.

4. Triangulasi

Dalam teknik pengumpulan data, triangulasi diartikan sebagai teknik pengumpulan data yang bersifat menggabungkan dari berbagai teknik pengumpulan data dan sumber data yang telah ada (Sugiyono, 2010, hlm 312).

5. Teknik Analisis Data

Analisis data yaitu proses penyederhanaan data kebentuk yang lebih mudah dibaca dan diinterprestasikan. Data-data yang berhadil dihimpun selama penelitian lapangan dianalisis dengan menggunakan pedoman tiga tahap analisis data model Miles dan Huberman sebagaimana yang dikutip oleh Sugiyono. Adapun aktivitas analisis data adalah Data Relation, Data Display, dan Conclusion Drawing / Verification.

a. Redukasi data (Data Reducation), dimaksudkan sebagai langkah atau proses mengurangi atau membuang data yang tidak perlu. Menyederhanakan, memfokuskan, menyeleksi atau menajamkan data yang telah diperoleh.

b. Penyajian Data (Data Display), yaitu menyajikan data untuk melihat gambaran keseluruhan atau bagian-bagian tertentu dari penelitian tersebut.

c. Penarikan kesimpulan dan Verifikasi (Conclusion Drawing / Verification). Langkah selanjutnya adalah tahap penarikan kesimpulan berdasarkan temuan dan melakukan verifikasi data. Proses untuk mendapatkan bukti-bukti yang mendukung tahap pengumpulan data inilah yang dikenal dengan verifikasi data. 


\section{HASIL PENELITIAN DAN PEMBAHASAN}

1. Hasil

a. Mekanisme Program Tabungan Rencana Berhadiah.

Mekanisme merupakan sarana dan cara menjalankan sesuatu. Dengan kata lain mekanisme adalah cara kerja yang digunakan untuk pengoperasian dalam menjalankan sesuatu yang diperlukan agar lancar dalam pengambilan manfatnya. Oleh karena itu dapat diketahui mekanisme program tabungan rencana pada Bank Muamalat KCP Abepura berikut ini:

1) Persyaratan Yang Harus Dilengkapi Nasabah Untuk Membuat Buku TRB.

Untuk membuka rekening tabungan rencana berhadiah nasabah wajib menyertakan KTP (Kartu Tanda Penduduk) dan NPWP (jika ada).

2) Persyaratan Yang Harus Dipenuhi Nasabah Untuk Menjadi Nasabah TRB

Untuk menjadi nasabah tabungan rencana berhadiah nasabah telebih dahulu membuat buku rekening tabungan biasa dan buku rekening tabungan rencana berhadiah. Rekening tabungan biasa dibuat sebagai rekening penempatan dana dimana dana yang ada pada rekening tersebut akan terdebet secara otomatis ke rekening tabungan rencana berhadiah sesuai tanggal jatuh tempo setoran setiap bulan. Dan rekening tabungan rencana berhadiah adalah rekening pengendapan dana tabungan rencana berhadiah yang suatu saat akan di close secara otomatis ketika waktu jatuh tempo telah selesai.

3) Syarat Dan Ketentuan TRB

a) Dana fresh fund (pemindahan dana)

b) Minimum penempatan Rp 25 juta (berlaku kelipatan Rp 5 juta)

c) Jangka waktu pengendapan dana mulai dari 24 bulan (2 tahun) sampai 120 bulan (10 tahun) Nasabah yang menutup rekening sebelum jatuh tempo, dikenakan biaya penggantian hadiah sesuai dengan ketentuan Bank Muamalat

d) Warna hadiah tergantung persediaan

e) Hadiah sudah termasuk pajak

f) Hadiah dan skema yang dipilih tidak dapat ditukar dengan alasan apapun

g) Apabila hadiah tidak tersedia, Bank Muamalat dapat mengganti dengan hadiah lain yang setara

h) Daftar hadiah berubah sewaktu-waktu sesuai dengan ketentuan Bank Muamalat

i) Hadiah yang diberikan berupa barang (bukan diberikan ke nasabah dalam bentuk uang).

j) Hadiah bukan merupakan barang habis pakai seperti bahan baku dari suatu proses. Hadiah bukan barang yang perlu diolah lagi misalnya bahan bangunan, bahan baku pembuatan pakaian, bahan baku makanan dan sebagainya.

4) Kebijakan pihak bank ketika nasabah tabungan rencana berhadiah tidak melanjutkan tabungan tersebut sampai jangka waktu yang ditentukan nasabah

Ketika nasabah tidak melanjutkan tabungan tersebut (berhenti ditengah jalan) nasabah wajib mengganti hadiah $100 \%$ sesuai harga hadiah yang telah ditentukan pihak bank.Tetapi nasabah berhak mendapatkan setoran setiap bulan dan bagi hasil setiap bulannya.

5) Pihak bank mengelola dana yang telah disetorkan oleh nasabah TRB

Dana yang disetorkan nasabah akan dikelola bank sesuai prinsip syariah dimana dana tersebut akan disalurkan kepada lembaga pembiayaan.

b. Persepsi Nasabah Terhadap Program Tabungan Rencana Berhadiah

Persepsi merupakan suatu proses pemahaman ataupun pemberian makna atas gejala yang selalunya diproses oleh otak. Persepsi menjadi hal yang sangat penting 
dalam dunia perbankan. Karena persepsi persaingan perbankan sudah semakin ketat serta kesyariahannya sudah jelas menggunakan hukum-hukum Islam, jadi patut masyarakat untuk menggunakan produk bank syariah disbanding bank konvensional. Berikut persepsi nasabah terhadap program tabungan rencana berhadiah pada Bank Muamalat KCP Abepura.

Nasabah memiliki persepsi bahwa tabungan rencana berhadiah adalah tabungan yang akan membantu nasabah untuk merencanakan keuangan dikemudian hari dimana nasabah dapat memperoleh hadiah tanpa proses undian dimana hadiah yang diperoleh dapat dinikmati atau digunakan sesuai kebutuhan. Kemudian jumlah setoran awal, setoran bulanan serta bagi hasi setiap bulan akan kembali kepada nasabah dalam jangka waktu yang di telah tentukan. Nasabah dapat memperoleh informasi TRB dari berbagai strategi pemasaran yang dilakukan marketing salah satunya adalah pembagian brosur secara langsung. Dari pelayanan yang diberikan kepada nasabah, CS ataupun Teller telah memenuhi standar operasional dimana nasabah merasa nyaman dengan pelayanan yang ada di Bank Muamalat. TRB ini diminati nasabah karena berbasis syariah dan tujuan utama nasabah menggunakan TRB salah satunya adalah untuk masa depan anak.

Adapun persepsi nasabah lainnya tentang program tabungan rencana berhadiah bahwa tabungan rencana berhadiah sangat menguntungkan nasabah yang bisa memperoleh hadiah diawal dan memperoleh uang dikemudian hari setelah jangka waktu menabung telah selesai.Marketing dapat memberikan informasi tentang TRB secara detail kepada nasabah dimanapun tidak harus berkunjungke bank karena marketing setiap hari akan melakukan pemasaran mengenai produk atau program yang dimiliki bank muamalat. Dari penjelasan marketing tentang TRB, timbullah minat nasabah untuk menggunakan tabungan tersebut dengan tujuan mendapatkan hadiah dan keuntungan yang dapat digunakan untuk masa depan anak.Dan pelayanan yang diberikan CS ataupun Teller sangat memicu terhadap minat nasabah untuk tetap bertahan menggunakan tabungan rencana berhadiah tersebut.

Dan berbeda persepsi lagi dengan nasabah lain yang beranggapan bahwa bahwa tabungan rencana berhadiah adalah program tabungan yang bisa membantu nasabah untuk mengatur rencana keuangan dikemudian hari. Tujuan dari tabungan ini adalah untuk masa depan anak. Informasi yang diperoleh nasabah dari marketing Bank Muamalat sangat berpengaruh positif terhadap minat nasabah untuk mengikuti TRB tersebut.Termasuk dalam pelayanan yang diberikan CS (Costumer Service) ataupun Teller sangat mendukung terhadap minat nasabah untuk tetap mengikuti program TRB tersebut.

\section{Pembahasan}

a. Mekanisme Tabungan Rencana Berhadiah

Mekanisme dapat menghasilkan suatu pola atau bentuk yang ingin dicapai sesuai dengan tujuan secara teratur. Demikian, mekanisme yang telah dilakukan oleh Bank Muamalat KCP Abepura pada tabungan rencana berhadiah pada umumnya adalah nasabah membuat buku rekening tabungan biasa dan buku rekening tabungan rencana berhadiah. Dimana dana nasabah yang ada pada buku rekening tabungan biasa tersebut secara otomatis akan terdebet kerekening tabungan rencana berhadiah yang merupakan setoran setiap bulan. Dan rekening tabungan rencana menjadi wadah atau tempat pengendapan dana dari setoran awal, setoran bulanan dan bagi hasil setiap bulannya. Rekening tabungan rencana berhadiah secara otomatis akan diclose dari pihak bank ketika waktu menabung telah selesai dan semua dana akan dikembalikan kepada nasabah dengan jumlah setoran awal + setoran bulanan + bagi hasil 7,5\% akan ditransfer ke rekening tabungan rencana berhadiah milik nasabah itu sendiri. 
Pada program tabungan rencana berhadiah telah dicover oleh asuransi jiwa sehingga apabila terjadi resiko seperti meninggal dunia maka tabungan akan diakhiri. Setoran awal, setoran bulanan, serta bagi hasil akan kembali kepada nasabah secara keseluruhan tanpa pemotongan uang hadiah dan hadiah menjadi miliki nasabah/ahli waris. Dan apabila nasabah mengalami bencana alam, dalam hal ini nasabah benarbenar tidak mampu untuk membayar setoran setiap bulan maka secara otomatis program tersebut akan berhenti dengan ketentuan setoran awal + setoran bulanan + bagi hasil akan kembali kepada nasabah tanpa potongan biaya apapun dan hadiah akan menjadi milik nasabah.

Ketika waktu menabung nasabah telah selesai maka, secara otomatis rekening tabungan rencana berhadiah akan ditutup (close) dan dana yang ada pada tabungan tersebut akan ditransfer kerekening tabungan biasa milik nasabah itu sendiri.

Agar lebih jelas dan sistematis berikut bagan atau sistematika program tabungan rencana berhadiah yang akan menjelaskan mekanisme program tabungan rencana berhadia.

Skema mekanisme program tabungan rencana berhadiah.

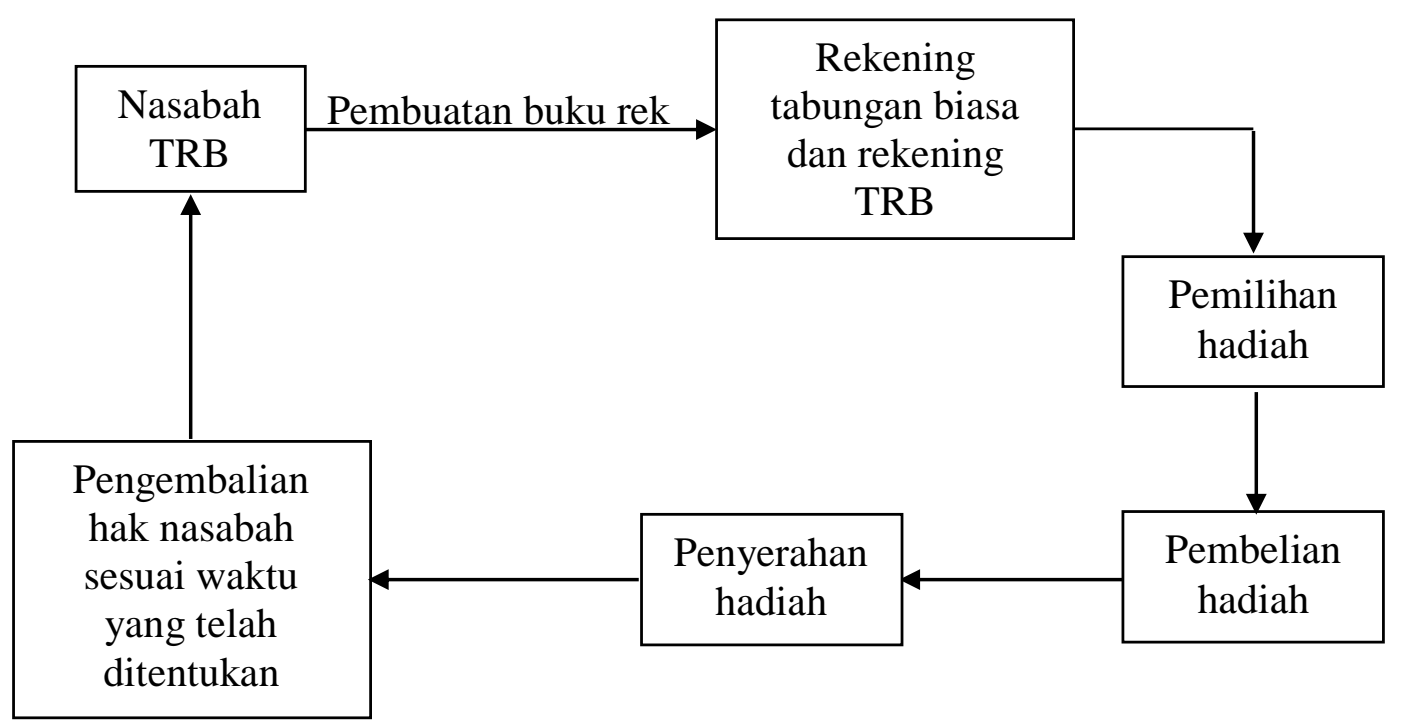

Sumber Data : Diolah oleh peneliti

Keterangan :

1. Nasabah TRB merupakan orang yang telah melakukan prosedur tabungan rencana berhadiah secara pribadi atau tidak dapat diwakilkan.

2. Rekening tabungan biasa dan rekening TRB. Penempatan dana disimpan pada rekening tabungan biasa yang akan didebet oleh pihak bank ke rekening TRB sesuai jatuh tempo setoran bulanan dan pengendapan dana disimpan pada rekening tabungan rencana berhadiah yang akan diblokir sesuai waktu menabung yang telah ditentukan. Dana yang dimaksud pada rekening tabungan rencana berhadiah adalah dana setoran awal, setoran bulanan dan bagi hasil setiap bulannya.

3. Pemilihan hadiah. Hadiah dipilih langsung oleh nasabah yang bersangkutan tidak dapat diwakilkan. 
4. Pembelian hadiah. Dalam pembelian hadiah tersebut akan dilakukan oleh pihak bank tidak dapat dilakukan oleh nasabah. Dan nasabah tidak diperkenankan menambah uang pribadi dalam pembelian hadiah.

5. Penyerahan hadiah. Hadiah di serahkan kepada nasabah yang bersangkutan atau tidak dapat wakilkan dan proses peneyerahan hadiah dapat dilakukan dimana saja baik itu di Bank Muamalat atau di rumah nasabah itu sendiri.

6. Pengembalian hak nasabah sesuai waktu yang telah ditentukan. Hak nasabah dimaksud dalam hal ini adalah setoran awal + setoran bulanan + bagi hasil 7,5\% setiap bulannya akan kembali kepada nasabah yang secara otomatis akan ditransfer kerekening tabungan biasa. Dan rekening tabungan rencana berhadiah otomatis akan di close oleh pihak bank ketika waktu menabung telah selesai.

b. Persepsi Nasbah Terhadap Program Tabungan Rencana Berhadiah

Persepsi bersifat individual yaitu persepsi dapat dikemukakan karena perasaan, kemampuan berfikir, pengalaman individu tidak sama, maka dalam mempersepsi sesuatu stimulus, hasil persepsi akan berbeda antara individu satu dengan individu lain.

Persepsi merupakan point bagi lahirnya macam perilaku seperti apa yang akan dilakukan oleh manusia. Dengan kata lain, persepsi adalah potensi yang sewaktuwaktu siap diaktualisasikan dalam bentuk sikap dan perilaku.

Oleh karena itu dapat diketahui bahwa persepsi menjadi hal yang sangat penting khususnya dalam dunia perbankan. Karena persaingan perbankan sudah semakin ketat ditinjau dari hukum dalam akad-akadnya serta produk dan programyang menarik. Demikian, persepsi nasabah terhadap salah satu program Bank Muamalat KCP Abepura yaitu Program Tabungan Rencana Berhadiah. Berikut teori yang dapat menjelaskan persepsi nasabah terhadap program TRB diantaranya :

1. Fisiologi. Informasi masuk melalui alat indera, selanjutnya informasi yang diperoleh akan mempengaruhi dan melengkapi usaha untuk memberikan arti terhadap lingkungan sekitarnya. Persepsi pada setiap orang berbeda-beda sehingga interpretasi terhadap lingkungan dan benda juga dapat berbeda.

Informasi dapat diperoleh nasabah melalui berbagai cara baik itu langsung dari Bank Muamalat, dari marketing, penyebaran brosur dan lain-lain sesuai strategi pemasaran yang dilakukan Bank Muamalat. Dari informasi tersebut maka timbullah persepsi nasabah terhadap tabungan rencana berhadiah, dimana nasabah beranggapan bahwa tabungan rencana berhadiah sangat menguntungkan karena tabungan ini dapat membantu nasabah merencanakan keuangannya dikemudian hari dengan cara menabung setiap bulan sesuai jangka waktu yang ditentukan oleh nasabah dan nasabah juga bisa menikmati hadiah yang telah didapatkan diawal sesuai keinginan dan kebutuhan nasabah.

2. Minat. Merupakan dorongan atau keinginan dalam diri seseorang pada objek tertentu.

Dalam hal ini yang mendorong minat nasabah untuk menggunakan tabungan rencana berhadiah adalah karena nasabah mempunyai tujuan. Dari tujuan itulah nasabah sangat terdorong dan ambisi untuk mencapai keinginan tersebut, dimana tujuan yang dimaksud adalah untuk masa depan anak-anak mereka dikemudian hari yang berupa jenjang pendidikan karena tabungan ini jangka waktu menabungnya sangat lama sehingga nasabah dapat mengumpulkan dana pada program tabungan rencana berhadiah sesuai jangka waktu yang ditentukan dan nasabah dapat mengambil kembali dana yang telah ditabung 
selama bertahun-tahun setelah waktu menabung selesai dan dapat digunakan sesuai kebutuhan nasabah.

3. Pengalaman. Kejadian yang pernah dialami (dijalani, dirasai, ditanggung dan sebagainya) baik yang sudah lama atau baru saja terjadi.

Pengalaman nasabah selama menggunakan tabungan rencana berhadiah menjadi tantangan tersendiri atau tanggung jawab terhadap dana yang harus disetorkan setiap bulannya. Namun, hal ini tidak mengurangi usaha nasabah untuk selalu melakukan setoran karena menurut nasabah dari kita untuk kita dengan arti bahwa dana yang disetorkan akan kembali kepada nasabah setelah waktu menabung selesai. Dan hal ini bisa menjadi pelajaran untuk nasabah bahwa dalam mencapai tujuan harus dengan usaha dan tanggung jawab yang maksimal.

4. Suasana hati. Suatu bentuk keadaan atau mood seseorang yang menunjukkan bagaimana perasaan seseorang pada waktu yang dapat mempengaruhi seseorang dalam menerima stimulusatau kejadian tertentu.

Suasana hati meliputi perasaan seseorang terhadap objek tertentu.Begitu juga dengan perasaan nasabah sebelum dan setelah menggunakan tabungan rencana berhadiahyang menyatakan bahwa awalnya memang merasa begitu tertarik apa lagi setelah mengetahui keuntungan-keuntungan yang didapat. Namun, setelah berjalan selama beberapa lama sekitar 2-3 tahun barulah terasa bebannya terutama untuk mengangsur setoran setiap bulan kepada bank. Akan tetapi, terlepas dari hal tersebut nasabah tetap berharap beban yangterasa berat tersebut tidak akan sia-sia karena ke depannya akan sudah memiliki jaminan untuk sebuah tujuan yang ingin dicapai.

\section{KESIMPULAN DAN SARAN}

Kesimpulan

1. Mekanisme program tabungan rencana berhadiah dibekali dengan buku rekening tabungan biasa dan buku rekening tabungan rencana berhadiah. Dimana rekening tabungan biasa sebagai penempatan dana yang akan didebet secera otomatis oleh pihak bank ketika setoran setiap bulan telah jatuh tempo dan rekening tabungan rencana berhadiah sebagai tabungan pengendapan dana yang dikemudian hari akan di close secara otomatis oleh pihak bank ketika jangka waktu menabung telah selesai. Dengan ketentuan hadiah yang diterima diawal berupa barang tidak berupa uang tunai. Jumlah setoran awal + setoran bulanan + bagi hasil 7,5\% setiap bulannya semua akan kembali kepada nasabah sesuai jangka waktu menabung yang ditentukan oleh nasabah dan pihak bank.

2. Persepsi nasabah terhadap program tabungan rencana berhadiah sangat bernilai positif yang dapat mempengaruhi citra perusahaan, kualitas program maupun produk yang dimiliki Bank Muamalat KCP Abepura dan meningkatkan minat nasabah untuk menabung di Bank Muamalat. Karena dengan adanya tabungan ini nasabah merasa terbantu untuk merencanakan keuangannya dikemudian hari yang salah satu tujuan dari tabungan tersebut adalah untuk masa depan anak (pendidikan anak). Nasabah juga mengakui bahwa pelayanan yang diberikan Bank Muamalat betul-betul sesuai standar operasional, dimana nasabah dilayani dengan cepat, baik, sopan,ramah, dan sabagaimana mestinya melayani tamu. Dan informasi yang diberikan sangat jelas dan mudah dimengerti oleh nasabah. 
Saran

1. Dengan dilakukannya penelitian ini dapat meberikan wawasan tambahan dan bahan bacaan baru untuk mahasiswa FEBI di IAIN FATTAHUL MULUK PAPUA yang akan melakukan penelitian selanjutnya dan diharapkan dalam penelitian berikutnya lebih bagus serta kelengkapan data yang lebih detail.

2. Dari hasil penelitian ini dapat memberi informasi kepada masyarakat umum mengenai program tabungan rencana berhadiah yang dimiliki oleh Bank Muamalat sehingga menjadi bahan referensi dan pertimbangan keputusan untuk menarik minat masyarakat dalam menggunakan program tabungan ini.

3. Dalam hasil penelitian ini, terbentuknya program tabungan rencana berhadiah pada Bank Muamalat KCP Abepura menunjukkan kualitas yang baik. Untuk itu diharapkan dari hasil penelitian ini bisa dijadikan sebagai bahan evaluasi oleh pihak Bank Muamalat KCP Abepura dan dapat meningkatkan kualitas pada Tabungan Rencana Berhadiah serta tetap menjaga kepercayaan yang telah diberikan nasabah kepada pihak Bank Muamalat KCP Abepura.

\section{DAFTAR REFERENSI}

Aminah. S dan Roikan, "Pengantar Motode Penelitian Kuaitatif Ilmu Politik" (Jakarta Timur: Kencana, 2019)

Bagus Lorens, “Kamus Filsafat” (Jakarta: Gramedia, 1996)

Elgita Arum Dwiyanti, “Analisis Pengaruh Kualitas PelayananTerhadap Minat Nasabah Pada Produk Berjangka (Deposito, Tabungan Prima Berhadiah dan Tabungan Rencana Berhadiah) di Bank Muamalat Indonesia KCU Pondok Indah" Universitas Islam Negeri Sunan Kalijaga, Yogyakarta, Tahun 2018.

Fitrah. Muh dan Luthfiyah, "Metodologi Penelitian, Penelitian Kualitatif, Tindakan Kelas Dan Studi Kasus" (Jawa Barat: CV Jejak, 2017)

Hamdi Saepul Asep, "Metode Penelitian Kualitatif Aplikasi Dalam Pendidikan" (Yogyakarta: Deepublish, 2014)

Hermawan Iwan, "Teknik Menulis Karya Ilmiah Berbasis Aplikasi Dan Metodologi", (Kuningan:HidayatulQur'an,2019)

http://pusatbahasa.diknas.go.id/kbbi/index.php diakses pada 22 Januari 2020.

Juliandi Andi, Irfan dan Manurung Saprina, "Metodologi Penelitian Bisnis Konsep Dan Aplikasi” (Medan: UMUS Press, 2014)

Kasmir, "Dasar-Dasar Perbankan" (Jakarta: PT. Raja Grafindo Persada, 2008) Kotler Philip, "Manajemen Pemasaran" (Jakarta:Erlangga, 2008)

Khairin Makmun, "Psikologi Umum” (Yogyakarta: Aswaja Presindo, 2016)

Kotler Philip dan Keller Lane Kevin, "Manajemen Pemasaran Edisi 12” (Indonesia, PT Macanan Jaya Cemerlang, 2009) 
Machmud, Amir dan Rukman, “Bank Syariah” (PT. Gelora Aksara Pratama, 2010)

Nurhaeni, "Persepsi Nasabah Islam Terhadap Tabungan Haji Pada Unit BNI Syariah Cabang Makassar”, Universitas Islam Negeri Alauddin, Makassar, Tahun 2012.

Oktavia Fadmawati,"Analisis Persepsi Pengetahuan Dan Sikap Nasabah Terhadap Keberadaan Bank Syariah”, Universitas Islam Negeri Raden Intan, Lampung, Tahun 2018.

Rangkuti Freddy, “The Power of Brand” (Jakarta: Gramedia Pusaka Utama, 2002.)

Sariati, "Persepsi Nasabah Terhadap Image Produk Pembiayaan Pasca Konversi Bank Aceh”, Universistas Islam Negeri Ar-Raniry, BandahAceh, Tahun 2018.

Setiadi J Nugroho, "Perilaku Konsumen dan Implementasi Untuk Strategi dan Penelitian, Pemasaran" (Jakarta: Penanda Media Group, 2013)

Tri Astuti, Jurnal "Pengaruh Persepsi Nasabah Tentang Tingkat Suku Bunga, Promosi dan Kualitas Pelayanan Terhadap Minat Menabung Nasabah”,Universitas Negeri Yogyakarta, Vol 2, No 1: 2013. 